\title{
Chapter 23 \\ The Role of Th1 Cytokines on Mechanical Loading-Induced Osteoclastogenesis and Bone Resorption
}

\author{
Hideki Kitaura, Keisuke Kimura, Masahiko Ishida, Zaki Hakami, \\ Jafari Saeed, Haruki Sugisawa, Haruka Kohara, Masako Yoshimatsu, \\ and Teruko Takano-Yamamoto
}

\begin{abstract}
Mechanical loading exerts important effects on the skeleton by controlling bone mass and strength. Osteoclasts are required for bone resorption and remodeling. Two cytokines are required for osteoclast formation: macrophage colony-stimulating factor and receptor activator of nuclear factor kappa-B ligand (RANKL). Tumor necrosis factor- $\alpha(\mathrm{TNF}-\alpha)$ has also been recognized as an important factor for osteoclastogenesis. It has previously been reported that interleukin (IL)-12 and IL-18, and interferon gamma (IFN- $\gamma$ ), which are type 1T helper cell (Th1) cytokines, inhibited RANKL- and TNF- $\alpha$-mediated osteoclastogenesis. It also been reported that TNF- $\alpha$ plays an important role in mechanical loadinginduced osteoclastogenesis and bone resorption. Orthodontic tooth movement is a good model for exploring the mechanism underlying mechanical loading-induced bone changes. Orthodontic tooth movement in a mouse model was established, and we investigated whether Th1 cytokines such as IL-12 and IFN- $\gamma$ inhibit osteoclastogenesis and bone resorption upon mechanical loading. The number of tartrateresistant acid phosphatase (TRAP)-positive cells increased at the pressure side of the first molar. Conversely, the amount of tooth movement and the number of TRAP-positive cells at the pressure side in IL-12- and IFN- $\gamma$-injected mice was less than that of non-injected mice. The results suggested that IL-12 and IFN- $\gamma$ might have an inhibitory effect on mechanical loading-induced osteoclastogenesis. In this review, we describe and discuss the effect of Th1 cytokines on mechanical loadinginduced osteoclastogenesis and bone resorption.
\end{abstract}

H. Kitaura • K. Kimura • M. Ishida • Z. Hakami • J. Saeed • H. Sugisawa

T. Takano-Yamamoto $(\bowtie)$

Division of Orthodontics and Dentofacial Orthopedics, Department of Translational Medicine,

Tohoku University Graduate School of Dentistry, 4-1 Seiryo-machi, Aoba-ku,

Sendai 980-8575, Japan

e-mail: t-yamamo@m.tohoku.ac.jp

H. Kohara • M. Yoshimatsu

Department of Orthodontics and Dentofacial Orthopedics, Nagasaki University Graduate

School of Biomedical Sciences, Nagasaki 852-8588, Japan 
Keyword Bone resorption • Osteoclast • Th1 cytokines

\subsection{Osteoclast Differentiation}

Bone resorption is controlled by osteoclasts. Osteoclasts differentiate from hematopoietic stem cells [1]. Several important factors for osteoclast differentiation have been recognized. The receptor activator of nuclear factor kappa-B ligand (RANKL) [2], also known as osteoclast differentiation factor (ODF) [3], osteoprotegerin ligand (OPGL) [4], and tumor necrosis factor (TNF)-related activation-induced cytokine (TRANCE) [5] have been found to be essential in osteoclast differentiation. Macrophage colony-stimulating factor (M-CSF) is also identified as essential for the proliferation and differentiation of osteoclast precursors [6]. Op/op mice, which lack functional M-CSF, show osteopetrosis and have no osteoclasts. This deficiency can be cured by injection of M-CSF [7]. RANKL has been identified as a ligand of the receptor activator of nuclear factor kappa-B (RANK), which is an immunoresponsive receptor on dendritic cells [2]. RANKL-deficient mice have severe osteopetrosis and show a complete deficiency of osteoclasts [8]. Conversely, it has been reported that TNF- $\alpha$ also mediates osteoclast formation in vitro [9-11] and in vivo $[12,13]$. TNF- $\alpha$ can also form osteoclasts independent of RANKL in the presence of transforming growth factor beta (TGF- $\beta$ ) [14]. However, it has been reported in another group that TNF- $\alpha$ failed to induce the differentiation of osteoclasts without RANKL [15]. They suggested that a constitutive level of RANKL was necessary for TNF- $\alpha$-mediated osteoclast formation. Further studies are necessary to clarify this aspect.

\subsection{TNF- $\alpha$-Mediated Osteoclast Formation}

TNF- $\alpha$ is pleiotropic and has a variety of biological effects in a cell-specific manner. TNF- $\alpha$ is known to play a major role in host defense, and exerts proinflammatory activities through various cells, including mononuclear phagocytes, in which it is responsible for the activation of bactericidal and cytocidal systems $[16,17]$. It has been reported that TNF- $\alpha$ induces osteoclast formation from M-CSF-dependent bone marrow-derived macrophages in vitro [10]. TNF- $\alpha$ induced osteoclast recruitment might be central to the pathogenesis of inflammatory disorders [18]. TNF- $\alpha$ is a known contributor to rheumatoid arthritis [19], periodontal diseases [20,21], and postmenopausal osteoporosis [22]. The findings that TNF- $\alpha$ recognizes two receptors on cell surfaces, type 1 or p55 (TNFR1) and type 2 or p75 receptors (TNFR2), and that each receptor is capable of distinct intracellular signaling [23], has substantially deepened our understanding of the complex activities of this cytokine. Analysis of TNFR1- and TNFR2-deficient mice revealed that TNFR1 induces osteoclast differentiation, while TNFR2 inhibits osteoclast 
differentiation [24]. The role of TNF- $\alpha$ signaling in osteoclastogenesis remains poorly understood, and further studies are needed to clarify the relationship between TNF- $\alpha$ and osteoclast differentiation.

\subsection{Mechanical Force Loading-Induced Osteoclast Formation and Bone Resorption}

Mechanical loading force affects the skeleton by controlling bone mass and strength [25]. Several in vivo experimental models have been reported that evaluate the effect of mechanical loading on bone metabolism. The following experimental animal models have been established: jumping [26, 27], treadmill running [26, 28], squatting [29], and swimming [30]. Assessing an orthodontic tooth movement model in vivo is beneficial to understand the mechanism of mechanical loading-induced bone remodeling [31-34]. The animal models used for orthodontic tooth movement were usually rats and mice [35-43]. Opportunities for the use of various genemutated mice including those with genes that regulate bone metabolism have increased, because molecular biology techniques have progressed. Therefore, the mice tooth movement models can provide an understanding of the molecular mechanisms involved not only in tooth movement but also in mechanical loadinginduced bone remodeling. A nickel-titanium (Ni-Ti) coil spring to obtain a continuous force for tooth movement is suitable for exerting continuous orthodontic force in mice models $[44,45]$. The process of orthodontic tooth movement occurs by repeated alveolar bone resorption on the pressure side and bone formation on the tension side of teeth [46]. In orthodontic tooth movement, there is an association between osteoclasts and bone resorption on the pressure side [47]. In mice models, bone resorption was recognized on the pressure side and tartrate-resistant acid phosphatase (TRAP)-positive multinuclear cells also appeared on this side.

Mechanical force is relevant to tooth movement via the biological responses of cells in the periodontal ligament, alveolar bone, and other periodontal tissues [48]. Several factors, specifically cytokines and hormones, are related to this process. An increase in the level of TNF- $\alpha$ in the gingival sulcus during orthodontic tooth movement in humans has been reported $[49,50]$. TNF- $\alpha$ has been shown to be expressed in rat periodontal tissue during excessive orthodontic force application [51]. When tooth movement was applied to TNFR1- and TNFR2-deficient mice, the amount of tooth movement observed in TNFR2-deficient mice was less than that in the wild-type mice [44]. These results suggested that TNFR2 is important for orthodontic tooth movement. However, it has been reported that the analysis of the reaction to TNF- $\alpha$ using TNFR1- or TNFR2-deficient mice showed the induction of osteoclastogenesis in TNFR1-deficient mice, whilst the inhibition of osteoclastogenesis was observed in TNFR2-deficient mice [20]. These results are controversial. In the evaluation of the role of TNFR1 in osteoclast formation during orthodontic tooth movement, the number of osteoclasts in TNFR1-deficient mice 
was found to be lower than that in wild-type mice [52]. To further investigate the role of TNFRs, tooth movement experiments using double-mutated mice for both TNFR1 and TNFR2 were performed. The experiment showed significant decreases in the amount of tooth movement in the double-mutated mice [45]. These results suggested that TNF- $\alpha$ is associated with orthodontic tooth movement. However, the relationship between orthodontic movement and TNF- $\alpha$ is not yet completely understood.

\subsection{Effect of Interleukin (IL)-12 on Osteoclast Formation}

IL-12 is one of the type 1T helper cell (Th1) cytokines. IL-12 has been recognized as playing an important role in host defense. It induces differentiation of native $\mathrm{T}$ cells into IFN- $\gamma$-producing Th1 cells that are resistant to infection [53]. IL-12 is a heterodimeric disulfide-linked $70-\mathrm{kDa}$ protein consisting of 35- and 40-kDa subunits. It has previously been shown that IL-12 plays an important role in attaining the optimal level of cell-mediated immune response against intracellular pathogens [54]. IL-12 is produced by osteoblasts infected with Staphylococcus aureus, which is the most prevalent causative microorganism in osteomyelitis, a bone resorption disorder [55].

It has been shown that IL-12 inhibits osteoclast formation in the spleen cells of mice treated with M-CSF and RANKL [56]. It was found that the inhibitory effect of IL-12 depends on the presence of T cells among spleen cells. However, it has been reported that osteoclastogenesis induced by RANK/RANKL interaction decreased in the presence of IL-12 by a T-cell-independent mechanism in vitro [57], and TNF- $\alpha$-induced osteoclastogenesis was also inhibited through induction of apoptosis mediated by the interaction of the IL-12-induced Fas ligand (FasL) and TNF- $\alpha$-induced Fas in vitro [58]. IL-12 and IL-18 inhibited TNF- $\alpha$-mediated osteoclastogenesis by up-regulating FasL synergistically [59]. IL-18 is also an important Th1 cytokine. It has been reported that IL-18 can also inhibit osteoclast formation in spleen cell cultures in vitro and that the IL-18-mediated inhibition of osteoclast formation is also $\mathrm{T}$ cell dependent [56].

The target cells of IL-12 have been shown to be T cells [54], natural killer (NK) cells [60], natural killer $\mathrm{T}$ cells, B cells [61], dendritic cells [62], and macrophages [63]. It has been reported that IL-12 influences non-adherent cells in bone marrow cell cultures and induces FasL expression in non-adherent cells. The results suggested that adherent cells, such as dendritic cells and macrophages, are not target cells [54]. In addition, when bone marrow macrophages were co-cultured with $\mathrm{T}$ cells isolated from among spleen cells in the presence of M-CSF, TNF- $\alpha$, and IL-12 in vitro, apoptotic alterations were not observed [58]. In the study, when whole bone marrow cells from T-cell-deficient nude mice were cultured in the presence of M-CSF, TNF- $\alpha$, and IL-12, the cells underwent apoptosis similar to those of wild-type mice [58]. These results also 
suggest that $\mathrm{T}$ cells may not be target cells for IL-12 in this case. However, additional experiments are necessary to clarify the target cells for IL-12.

The effect of IL-12 on mechanical tooth movement in mice has been reported. Mechanical tooth movement, in which a Ni-Ti closed coil spring was inserted between the upper incisors and the first molar in mice, was used. IL-12 was injected into a local site adjacent to an upper molar during tooth movement. After 12 days, the distance of tooth movement was measured. The number of osteoclasts, which are TRAP-positive cells, were counted in a histological section. Tooth movement was inhibited when IL-12 was localized. The number of TRAP-positive cells was reduced in IL-12-treated mice [64].

Root resorption is a disagreeable phenomenon of orthodontic treatment, which may present at the dentinal and cemental areas of the tooth root surface, and is a serious problem for the orthodontist [65]. Even under normal conditions, it is possible to cause root resorption during orthodontic tooth movement [66-68]. Inhibition of root resorption is hopeful for orthodontists. In recent years, there have been studies investigating the use of medicine for future clinical application to prevent root resorption. It has been reported that bisphosphonates inhibit root resorption [69, 70]. In addition, it has been shown that osteoprotegerin inhibits root resorption more effectively than bisphosphonates [71]. Furthermore, the inhibitory effect on root resorption by amelogenin [72], bisphosphonates, and anti-c-Fms antibodies has also been reported [73, 74]. Root resorption was recognized in this tooth movement model. The root resorption area was measured using a scanning electron microscope. The root resorption area was reduced in IL-12-treated mice. In TdT-mediated dUTP-biotin nick end-labeling (TUNEL) assays, many apoptotic cells were seen on the pressure side in IL-12-treated mice. These findings indicate that IL-12 inhibits mechanical tooth movement and root resorption in orthodontic tooth movement. These results might be the outcome of apoptosis induced by IL-12.

\subsection{Effect of IFN- $\gamma$ on Osteoclast Formation and Bone Resorption}

IFN- $\gamma$ contributes to $\mathrm{T}$-cell-mediated regulation of immune responses and is secreted by Th1 cells, cytotoxic T cells, dendritic cells, and NK cells [75]. In addition, IFN- $\gamma$ has been recognized as an activator of macrophages because of the induction both of nitric oxide production and major histocompatibility complex presentation in macrophages, and exhibits antiviral and antibacterial activity [76].

The effect of IFN- $\gamma$ has been recognized as suppression of osteoclast formation by inhibition of RANKL signaling via degradation of TNF receptor-associated factor 6 [77]. Furthermore, the bone resorption in collagen-induced arthritis was enhanced in IFN- $\gamma$-deficient mice [78]. These data indicated that IFN- $\gamma$ inhibited osteoclast formation and bone resorption. However, it has been reported that IFN- $\gamma$ 
indirectly stimulates osteoclast formation via antigen-driven T-cell activation [79]. Therefore, the role of IFN- $\gamma$ in osteoclast formation is still unclear.

It has been reported that IFN- $\gamma$ directly inhibits osteoclastogenesis induced by TNF- $\alpha$ stimulation and accelerates apoptosis mediated by Fas/FasL signals. IFN- $\gamma$ directly interrupted TNF- $\alpha$-induced osteoclast formation as revealed with a decreased number of osteoclasts and messenger ribonucleic acid (mRNA) levels of nuclear factor of activated T cells, cytoplasmic 1 (NFATc1), which is a gene essential for osteoclast formation, in cultured bone marrow macrophages. Apoptotic findings of cultured cells were evaluated by accelerated nuclear fragmentation in osteoclast precursor cells. Fas mRNA levels in bone marrow cells were stimulated by TNF- $\alpha$. FasL mRNA levels in a bone marrow culture with IFN- $\gamma$ was increased. Furthermore, IFN- $\gamma$ inhibited osteoclastogenesis in response to TNF- $\alpha$ treatment in vivo. IFN- $\gamma$ inhibited TNF- $\alpha$-induced osteoclastogenesis in mice with $\mathrm{T}$ cells blocked by anti-CD4 and anti-CD8 antibodies [80]. These results suggested that IFN- $\gamma$ directly inhibits osteoclastogenesis, and induces cell apoptosis by Fas/FasL signaling, leading to the indirect regulation of bone resorption. This might occur as a protective role against bone destruction at an inflammation site.

The cellular responses in periodontal tissue, including the alveolar bone, periodontal ligament, and other periodontal tissues, during mechanical forcedriven tooth movement are mediated by interactions between various factors such as cytokines and hormones $[48,81]$. In a rat tooth movement model, IFN- $\gamma$ is expressed on the pressure side of teeth [82]. IFN- $\gamma$, which increases trabecular bone volume, has been evaluated histomorphometrically during orthodontic tooth movement in rats [83]. Therefore, these results suggest that IFN- $\gamma$ plays an important role in orthodontic tooth movement. However, there are few studies on the effect of IFN- $\gamma$ on tooth movement. The effect of IFN- $\gamma$ on mechanically loaded tooth movement in a mouse model has been reported. A Ni-Ti closed coil spring was inserted between the upper anterior alveolar bone and the upper left first molars in mice. The relationship between local IFN- $\gamma$ mRNA levels and orthodontic tooth movement was evaluated. In other experiments, IFN- $\gamma$ was injected to each first molar every other day during tooth movement. After 12 days, the amount of tooth movement was measured. The number of osteoclasts at the pressure side of each experimental tooth was assessed. Local IFN- $\gamma$ mRNA expression increased with orthodontic tooth movement in mice. The number of osteoclasts increased on the pressure side of the first molar. In contrast, the distance of tooth movement and the number of osteoclasts on the pressure side in IFN- $\gamma$-injected mice were less than those of control mice. IFN- $\gamma$ expression was increased in experimental tooth movement. Furthermore, IFN- $\gamma$ could inhibit mechanical force-induced osteoclast formation and tooth movement. These results suggest that IFN- $\gamma$ might be useful in controlling orthodontic tooth movement, because IFN- $\gamma$ inhibited the action of progressive osteoclast formation during orthodontic tooth movement [84]. These results lead us to conclude that IFN- $\gamma$ induction is able to inhibit mechanical force-loaded osteoclast formation, consequently inhibiting orthodontic tooth movement. 


\subsection{Conclusions}

It has been reported that many types of cytokines are expressed during mechanical loading of the periodontal ligament. TNF- $\alpha$ is an important molecule in mechanical loading force-induced osteoclast formation in the periodontal ligament during orthodontic tooth movement. Therefore, it is important to study the relationship between TNF- $\alpha$-induced osteoclast formation and the cytokines expressed during mechanical loading. Th1 cytokines inhibited osteoclast and odontoclast formation during mechanical loading in the periodontal ligament. There is a possibility that local injection of Th1 cytokines might be a useful tool to enhance the anchorage site and control the rate of tooth movement during orthodontic treatment, as well as prevent relapse after orthodontic treatment. Moreover, local injection of Th1 cytokines might be a useful tool in reducing root resorption, particularly for highrisk teeth. However, further studies are required to fully understand the relationship between mechanical loading-induced osteoclast formation and the effect of cytokines.

Open Access This chapter is distributed under the terms of the Creative Commons Attribution Noncommercial License, which permits any noncommercial use, distribution, and reproduction in any medium, provided the original author(s) and source are credited.

\section{References}

1. Suda T, Takahashi N, Martin TJ. Modulation of osteoclast differentiation. Endocr Rev. 1992;13(1):66-80.

2. Anderson DM, Maraskovsky E, Billingsley WL, Dougall WC, Tometsko ME, Roux ER, et al. A homologue of the TNF receptor and its ligand enhance T-cell growth and dendriticcell function. Nature. 1997;390(6656):175-9.

3. Yasuda H, Shima N, Nakagawa N, Yamaguchi K, Kinosaki M, Mochizuki S, et al. Osteoclast differentiation factor is a ligand for osteoprotegerin/osteoclastogenesis-inhibitory factor and is identical to TRANCE/RANKL. Proc Natl Acad Sci U S A. 1998;95(7):3597-602.

4. Lacey DL, Timms E, Tan HL, Kelley MJ, Dunstan CR, Burgess T, et al. Osteoprotegerin ligand is a cytokine that regulates osteoclast differentiation and activation. Cell. 1998;93 (2):165-76.

5. Wong BR, Rho J, Arron J, Robinson E, Orlinick J, Chao M, et al. TRANCE is a novel ligand of the tumor necrosis factor receptor family that activates c-Jun $\mathrm{N}$-terminal kinase in $\mathrm{T}$ cells. J Biol Chem. 1997;272(40):25190-4.

6. Kodama H, Nose M, Niida S, Yamasaki A. Essential role of macrophage colony-stimulating factor in the osteoclast differentiation supported by stromal cells. J Exp Med. 1991;173 (5):1291-4.

7. Begg SK, Radley JM, Pollard JW, Chisholm OT, Stanley ER, Bertoncello I. Delayed hematopoietic development in osteopetrotic (op/op) mice. J Exp Med. 1993;177(1):237-42.

8. Kong YY, Yoshida H, Sarosi I, Tan HL, Timms E, Capparelli C, et al. OPGL is a key regulator of osteoclastogenesis, lymphocyte development and lymph-node organogenesis. Nature. 1999;397(6717):315-23.

9. Azuma Y, Kaji K, Katogi R, Takeshita S, Kudo A. Tumor necrosis factor-alpha induces differentiation of and bone resorption by osteoclasts. J Biol Chem. 2000;275(7):4858-64. 
10. Kobayashi K, Takahashi N, Jimi E, Udagawa N, Takami M, Kotake S, et al. Tumor necrosis factor alpha stimulates osteoclast differentiation by a mechanism independent of the ODF/ RANKL-RANK interaction. J Exp Med. 2000;191(2):275-86.

11. Fuller K, Murphy C, Kirstein B, Fox SW, Chambers TJ. TNFalpha potently activates osteoclasts, through a direct action independent of and strongly synergistic with RANKL. Endocrinology. 2002;143(3):1108-18.

12. Kitaura H, Sands MS, Aya K, Zhou P, Hirayama T, Uthgenannt B, et al. Marrow stromal cells and osteoclast precursors differentially contribute to TNF-alpha-induced osteoclastogenesis in vivo. J Immunol. 2004;173(8):4838-46.

13. Kitaura H, Zhou P, Kim HJ, Novack DV, Ross FP, Teitelbaum SL. M-CSF mediates TNF-induced inflammatory osteolysis. J Clin Invest. 2005;115(12):3418-27.

14. Kim N, Kadono Y, Takami M, Lee J, Lee SH, Okada F, et al. Osteoclast differentiation independent of the TRANCE-RANK-TRAF6 axis. J Exp Med. 2005;202(5):589-95.

15. Lam J, Takeshita S, Barker JE, Kanagawa O, Ross FP, Teitelbaum SL. TNF-alpha induces osteoclastogenesis by direct stimulation of macrophages exposed to permissive levels of RANK ligand. J Clin Invest. 2000;106(12):1481-8.

16. Vassalli P. The pathophysiology of tumor necrosis factors. Annu Rev Immunol. 1992;10 (411):411-52.

17. Tracey KJ, Cerami A. Tumor necrosis factor, other cytokines and disease. Annu Rev Cell Biol. 1993;9(317):317-43.

18. Wong M, Ziring D, Korin Y, Desai S, Kim S, Lin J, et al. TNFalpha blockade in human diseases: mechanisms and future directions. Clin Immunol. 2008;126(2):121-36.

19. Redlich K, Hayer S, Ricci R, David JP, Tohidast AM, Kollias G, et al. Osteoclasts are essential for TNF-alpha-mediated joint destruction. J Clin Invest. 2002;110(10):1419-27.

20. Abu AY, Ross FP, Edwards J, Teitelbaum SL. Lipopolysaccharide-stimulated osteoclastogenesis is mediated by tumor necrosis factor via its P55 receptor. J Clin Invest. 1997;100 (6):1557-65.

21. Van Dyke TE, Serhan CN. Resolution of inflammation: a new paradigm for the pathogenesis of periodontal diseases. J Dent Res. 2003;82(2):82-90.

22. Kimble RB, Srivastava S, Ross FP, Matayoshi A, Pacifici R. Estrogen deficiency increases the ability of stromal cells to support murine osteoclastogenesis via an interleukin-1and tumor necrosis factor-mediated stimulation of macrophage colony-stimulating factor production. J Dent Res. 1996;271(46):28890-7.

23. Goeddel DV. Signal transduction by tumor necrosis factor. Chest. 1999;116:69S.

24. Abu-Amer Y, Erdmann J, Alexopoulou L, Kollias G, Ross FP, Teitelbaum SL. Tumor necrosis factor receptors types 1 and 2 differentially regulate osteoclastogenesis. J Biol Chem. 2000;275(35):27307-10.

25. Frost HM. On our age-related bone loss: insights from a new paradigm. J Bone Miner Res. 1997;12(10):1539-46.

26. Notomi T, Okazaki Y, Okimoto N, Saitoh S, Nakamura T, Suzuki M. A comparison of resistance and aerobic training for mass, strength and turnover of bone in growing rats. Eur $\mathrm{J}$ Appl Physiol. 2000;83(6):469-74.

27. Kodama Y, Umemura Y, Nagasawa S, Beamer WG, Donahue LR, Rosen CR, et al. Exercise and mechanical loading increase periosteal bone formation and whole bone strength in C57BL/ $6 \mathrm{~J}$ mice but not in C3H/Hej mice. Calcif Tissue Int. 2000;66(4):298-306.

28. Iwamoto J, Yeh JK, Aloia JF. Differential effect of treadmill exercise on three cancellous bone sites in the young growing rat. Bone. 1999;24(3):163-9.

29. Westerlind KC, Fluckey JD, Gordon SE, Kraemer WJ, Farrell PA, Turner RT. Effect of resistance exercise training on cortical and cancellous bone in mature male rats. J Appl Physiol. 1998;84(2):459-64.

30. Hart KJ, Shaw JM, Vajda E, Hegsted M, Miller SC. Swim-trained rats have greater bone mass, density, strength, and dynamics. J Appl Physiol. 2001;91(4):1663-8.

31. Storey E. The nature of tooth movement. Am J Orthod. 1973;63(3):292-314. 
32. Takano-Yamamoto T, Takemura T, Kitamura Y, Nomura S. Site-specific expression of mRNAs for osteonectin, osteocalcin, and osteopontin revealed by in situ hybridization in rat periodontal ligament during physiological tooth movement. J Histochem Cytochem. 1994;42 (7):885-96.

33. Ohba Y, Ohba T, Terai K, Moriyama K. Expression of cathepsin K mRNA during experimental tooth movement in rat as revealed by in situ hybridization. Arch Oral Biol. 2000;45 (1):63-9.

34. Kobayashi Y, Hashimoto F, Miyamoto H, Kanaoka K, Miyazaki-Kawashita Y, Nakashima T, et al. Force-induced osteoclast apoptosis in vivo is accompanied by elevation in transforming growth factor beta and osteoprotegerin expression. J Bone Miner Res. 2000;15(10):1924-34.

35. Hashimoto F, Kobayashi Y, Mataki S, Kobayashi K, Kato Y, Sakai H. Administration of osteocalcin accelerates orthodontic tooth movement induced by a closed coil spring in rats. Eur J Orthod. 2001;23(5):535-45.

36. Brudvik P, Rygh P. The initial phase of orthodontic root resorption incident to local compression of the periodontal ligament. Eur J Orthod. 1993;15(4):249-63.

37. Pavlin D, Dove SB, Zadro R, Gluhak-Heinrich J. Mechanical loading stimulates differentiation of periodontal osteoblasts in a mouse osteoinduction model: effect on type I collagen and alkaline phosphatase genes. Calcif Tissue Int. 2000;67(2):163-72.

38. Kaku M, Kohno S, Kawata T, Fujita I, Tokimasa C, Tsutsui K, et al. Effects of vascular endothelial growth factor on osteoclast induction during tooth movement in mice. J Dent Res. 2001;80(10):1880-3.

39. Tsuji Y, Yamaza T, Kido MA, Goto T, Nakata S, Akamine A, et al. Expression of cathepsin K mRNA and protein in odontoclasts after experimental tooth movement in the mouse maxilla by in situ hybridization and immunoelectron microscopy. Cell Tissue Res. 2001;303(3):359-69.

40. Gluhak-Heinrich J, Ye L, Bonewald LF, Feng JQ, MacDougall M, Harris SE, et al. Mechanical loading stimulates dentin matrix protein 1 (DMP1) expression in osteocytes in vivo. J Bone Miner Res. 2003;18(5):807-17. doi:10.1359/jbmr.2003.18.5.807.

41. Kohno S, Kaku M, Tsutsui K, Motokawa M, Ohtani J, Tenjo K, et al. Expression of vascular endothelial growth factor and the effects on bone remodeling during experimental tooth movement. J Dent Res. 2003;82(3):177-82.

42. Chung CR, Tsuji K, Nifuji A, Komori T, Soma K, Noda M. Micro-CT evaluation of tooth, calvaria and mechanical stress-induced tooth movement in adult Runx2/Cbfa1 heterozygous knock-out mice. J Med Dent Sci. 2004;51(1):105-13.

43. Kuroda S, Balam TA, Sakai Y, Tamamura N, Takano-Yamamoto T. Expression of osteopontin mRNA in odontoclasts revealed by in situ hybridization during experimental tooth movement in mice. J Bone Miner Metab. 2005;23(2):110-3.

44. Yoshimatsu M, Shibata Y, Kitaura H, Chang X, Moriishi T, Hashimoto F, et al. Experimental model of tooth movement by orthodontic force in mice and its application to tumor necrosis factor receptor-deficient mice. J Bone Miner Metab. 2006;24(1):20-7.

45. Kitaura H, Yoshimatsu M, Fujimura Y, Eguchi T, Kohara H, Yamaguchi A, et al. An anti-cFms antibody inhibits orthodontic tooth movement. J Dent Res. 2008;87(4):396-400.

46. Storey E. Tissue response to the movement of bones. Am J Orthod. 1973;64(3):229-47.

47. Yokoya K, Sasaki T, Shibasaki Y. Distributional changes of osteoclasts and pre-osteoclastic cells in periodontal tissues during experimental tooth movement as revealed by quantitative immunohistochemistry of H(+)-ATPase. J Dent Res. 1997;76(1):580-7.

48. Krishnan V, Davidovitch Z. On a path to unfolding the biological mechanisms of orthodontic tooth movement. J Dent Res. 2009;88(7):597-608.

49. Lowney JJ, Norton LA, Shafer DM, Rossomando EF. Orthodontic forces increase tumor necrosis factor alpha in the human gingival sulcus. Am J Orthod Dentofacial Orthop. 1995;108(5):519-24.

50. Uematsu S, Mogi M, Deguchi T. Interleukin (IL)-1 beta, IL-6, tumor necrosis factor-alpha, epidermal growth factor, and beta 2-microglobulin levels are elevated in gingival crevicular fluid during human orthodontic tooth movement. J Dent Res. 1996;75(1):562-7. 
51. Ogasawara T, Yoshimine Y, Kiyoshima T, Kobayashi I, Matsuo K, Akamine A, et al. In situ expression of RANKL, RANK, osteoprotegerin and cytokines in osteoclasts of rat periodontal tissue. J Periodontal Res. 2004;39(1):42-9.

52. Andrade Jr I, Silva TA, Silva GA, Teixeira AL, Teixeira MM. The role of tumor necrosis factor receptor type 1 in orthodontic tooth movement. J Dent Res. 2007;86(11):1089-94.

53. Berenson LS, Ota N, Murphy KM. Issues in T-helper 1 development-resolved and unresolved. Immunol Rev. 2004;202(157):157-74.

54. Scott P. IL-12: initiation cytokine for cell-mediated immunity. Science. 1993;260 (5107):496-7.

55. Bost KL, Ramp WK, Nicholson NC, Bento JL, Marriott I, Hudson MC. Staphylococcus aureus infection of mouse or human osteoblasts induces high levels of interleukin-6 and interleukin12 production. J Infect Dis. 1999;180(6):1912-20.

56. Horwood NJ, Udagawa N, Elliott J, Grail D, Okamura H, Kurimoto M, et al. Interleukin 18 inhibits osteoclast formation via $\mathrm{T}$ cell production of granulocyte macrophage colonystimulating factor. J Clin Invest. 1998;101(3):595-603.

57. Nagata N, Kitaura H, Yoshida N, Nakayama K. Inhibition of RANKL-induced osteoclast formation in mouse bone marrow cells by IL-12: involvement of IFN-gamma possibly induced from non-T cell population. Bone. 2003;33(4):721-32.

58. Kitaura H, Nagata N, Fujimura Y, Hotokezaka H, Yoshida N, Nakayama K. Effect of IL-12 on TNF-alpha-mediated osteoclast formation in bone marrow cells: apoptosis mediated by Fas/Fas ligand interaction. J Immunol. 2002;169(9):4732-8.

59. Kitaura H, Tatamiya M, Nagata N, Fujimura Y, Eguchi T, Yoshida N, et al. IL-18 induces apoptosis of adherent bone marrow cells in TNF-alpha mediated osteoclast formation in synergy with IL-12. Immunol Lett. 2006;107(1):22-31.

60. Yu Y, Hagihara M, Ando K, Gansuvd B, Matsuzawa H, Tsuchiya T, et al. Enhancement of human cord blood CD34+ cell-derived NK cell cytotoxicity by dendritic cells. J Immunol. 2001;166(3):1590-600.

61. Airoldi I, Gri G, Marshall JD, Corcione A, Facchetti P, Guglielmino R, et al. Expression and function of IL-12 and IL-18 receptors on human tonsillar B cells. J Immunol. 2000;165 (12):6880-8.

62. Fukao T, Matsuda S, Koyasu S. Synergistic effects of IL-4 and IL-18 on IL-12-dependent IFN-gamma production by dendritic cells. J Immunol. 2000;164(1):64-71.

63. Puddu P, Fantuzzi L, Borghi P, Varano B, Rainaldi G, Guillemard E, et al. IL-12 induces IFN-gamma expression and secretion in mouse peritoneal macrophages. J Immunol. 1997;159 (7):3490-7.

64. Yoshimatsu M, Kitaura H, Fujimura Y, Eguchi T, Kohara H, Morita Y, et al. IL-12 inhibits TNF-alpha induced osteoclastogenesis via a $\mathrm{T}$ cell-independent mechanism in vivo. Bone. 2009;45(5):1010-6.

65. Terai K, Takano-Yamamoto T, Ohba Y, Hiura K, Sugimoto M, Sato M, Kawahata H, Inaguma N, Kitamura $\mathrm{Y}$, Nomura $\mathrm{S}$. Role of osteopontin in bone remodeling caused by mechanical stress. J Bone Miner Res. 1999;14(6):839-49.

66. Sameshima GT, Sinclair PM. Predicting and preventing root resorption: Part II. Treatment factors. Am J Orthod Dentofacial Orthop. 2001;119(5):511-5.

67. Chan E, Darendeliler MA. Physical properties of root cementum: Part 5. Volumetric analysis of root resorption craters after application of light and heavy orthodontic forces. Am J Orthod Dentofacial Orthop. 2005;127(2):186-95.

68. Wierzbicki T, El-Bialy T, Aldaghreer S, Li G, Doschak M. Analysis of orthodontically induced root resorption using micro-computed tomography (Micro-CT). Angle Orthod. 2009;79(1):91-6.

69. Komatsu K, Shimada A, Shibata T, Shimoda S, Oida S, Kawasaki K, et al. Long-term effects of local pretreatment with alendronate on healing of replanted rat teeth. J Periodontal Res. 2008;43(2):194-200. 
70. Liu L, Igarashi K, Haruyama N, Saeki S, Shinoda H, Mitani H. Effects of local administration of clodronate on orthodontic tooth movement and root resorption in rats. Eur J Orthod. 2004;26 (5):469-73.

71. Keles A, Grunes B, Difuria C, Gagari E, Srinivasan V, Darendeliler MA, et al. Inhibition of tooth movement by osteoprotegerin vs. pamidronate under conditions of constant orthodontic force. Eur J Oral Sci. 2007;115(2):131-6.

72. Yagi Y, Suda N, Yamakoshi Y, Baba O, Moriyama K. In vivo application of amelogenin suppresses root resorption. J Dent Res. 2009;88(2):176-81.

73. Fujimura Y, Kitaura H, Yoshimatsu M, Eguchi T, Kohara H, Morita Y, et al. Influence of bisphosphonates on orthodontic tooth movement in mice. Eur J Orthod. 2009;31(6):572-7.

74. Kitaura H, Fujimura Y, Yoshimatsu M, Eguchi T, Kohara H, Jang I, et al. An M-CSF receptor c-Fms antibody inhibits mechanical stress-induced root resorption during orthodontic tooth movement in mice. Angle Orthod. 2009;79(5):835-41.

75. Dunn GP, Koebel CM, Schreiber RD. Interferons, immunity and cancer immunoediting. Nat Rev Immunol. 2006;6(11):836-48.

76. Billiau A, Heremans H, Vermeire K, Matthys P. Immunomodulatory properties of interferongamma. An update. Ann N Y Acad Sci. 1998;856:22-32.

77. Takayanagi H, Ogasawara K, Hida S, Chiba T, Murata S, Sato K, et al. T-cell-mediated regulation of osteoclastogenesis by signalling cross-talk between RANKL and IFN-gamma. Nature. 2000;408(6812):600-5.

78. Vermeire K, Heremans H, Vandeputte M, Huang S, Billiau A, Matthys P. Accelerated collagen-induced arthritis in IFN-gamma receptor-deficient mice. J Immunol. 1997;158 (11):5507-13.

79. Gao Y, Grassi F, Ryan MR, Terauchi M, Page K, Yang X, et al. IFN-gamma stimulates osteoclast formation and bone loss in vivo via antigen-driven $\mathrm{T}$ cell activation. J Clin Invest. 2007;117(1):122-32.

80. Kohara H, Kitaura H, Fujimura Y, Yoshimatsu M, Morita Y, Eguchi T, et al. IFN-gamma directly inhibits TNF-alpha-induced osteoclastogenesis in vitro and in vivo and induces apoptosis mediated by Fas/Fas ligand interactions. Immunol Lett. 2011;137(1-2):53-61.

81. Henneman S, Von den Hoff JW, Maltha JC. Mechanobiology of tooth movement. Eur J Orthod. 2008;30(3):299-306.

82. Alhashimi N, Frithiof L, Brudvik P, Bakhiet M. Orthodontic movement induces high numbers of cells expressing IFN-gamma at mRNA and protein levels. J Interferon Cytokine Res. 2000;20(1):7-12.

83. Mermut S, Bengi AO, Akin E, Kurkcu M, Karacay S. Effects of interferon-gamma on bone remodeling during experimental tooth movement. Angle Orthod. 2007;77(1):135-41.

84. Kohara H, Kitaura H, Yoshimatsu M, Fujimura Y, Morita Y, Eguchi T, et al. Inhibitory effect of interferon-gamma on experimental tooth movement in mice. J Interferon Cytokine Res. 2012;32(9):426-31. 